\title{
Familial recurrent peripheral facial palsy
}

INSERM

\section{Source}

INSERM. (1999). Orphanet: an online rare disease and orphan drug data base. Familial recurrent peripheral facial palsy. ORPHA:2809

Familial recurrent peripheral facial palsy is a rare peripheral neuropathy characterized by an acute onset of unilateral facial muscle weakness with Bell's phenomenon. It is nonprogressive, resolves spontaneously, and it might be recurrent with no obvious precipitating factors. 